\title{
A Mathematical Model of Desulphurization Kinetics for Ultra-low- sulfur Steels Refining by Powder Injection during RH Processing
}

\author{
Cheng-yi ZHU, ${ }^{1,2)}$ Peng-ju CHEN, ${ }^{1,2)}$ Guang-qiang LI, ${ }^{1,2,3) *}$ Xiao-yan LUO ${ }^{1,2)}$ and Wan ZHENG ${ }^{1,2)}$
}

1) The State Key Laboratory of Refractories and Metallurgy, Wuhan University of Science and Technology, Wuhan, Hubei, 430081 China. $\quad$ 2) Key Laboratory of Ferrous Metallurgy and Resources Utilization, Ministry of Education, Wuhan University of Science and Technology, Wuhan, Hubei, 430081 China. $\quad 3)$ Collaborative Innovation Center of Steel Technology, University of Science and Technology Beijing, Beijing, 100083 China.

(Received on March 8, 2016; accepted on April 13, 2016; J-STAGE Advance published date: June 16, 2016)

\begin{abstract}
A mathematical model about the variation of sulphur content in liquid steel during a $300 \mathrm{t} \mathrm{RH}$ refining process was established based on the consideration of thermodynamics, kinetics of desulphurization and conditions of practical production. The effect of initial sulphur content in the top slag on the ration of contribution of transitory desulphurization reaction in total desulphurization was included. The effects of initial sulphur content in the liquid steel, powder injection rate, particle size of powder, flow rate of $\mathrm{RH}$ driving gas and initial temperature of the bath on the temperature drop were taken into account. Sulphur content in the steel bath during desulphurization process and the final sulphur content in the liquid steel were analyzed. The lowest sulphur content can decrease to $10 \mathrm{ppm}$ from $30 \mathrm{ppm}$ by taking reasonable injection operating conditions to treat $10 \mathrm{~min}$. The simulated results of sulfur removal rate and final sulphur content in liquid steel agree well with that of plant production under the same conditions, which indicates that the present model can be used to predict desulphurization process. The simulated results also show that powder injection desulphurization has better desulphurization efficiency compared with adding desulphurization agent simply onto the top of molten steel in the vacuum vessel in the practical production process.
\end{abstract}

KEY WORDS: desulphurization; powder injection; kinetics; $\mathrm{RH}$; mathematical model.

\section{Introduction}

Sulphur is a harmful impurity for most steel grades. FeS in the steels will lead to hot shortness during hot rolling operations. Manganese is added in steel to prevent from forming low-melting FeS but brittle $\mathrm{MnS}$ inclusions with sharp edges can be formed in the steel and often precipitate on the grain boundaries. $\mathrm{CaS}$ and other oxygen-sulphide complex inclusions are also easily found in steels. Sulphide inclusions jeopardize microstructure uniformity of the steels, deteriorate mechanical properties and processing performance of the finished steel products. Smaller sulphide inclusions dispersed in the steels can easily become a source of dotting or pitting corrosion and impact corrosion resistance of the steels. ${ }^{1,2)}$ In order to meet service requirements of different applications, sulphur content is limited in some steel grades such as high-grade pipeline steels, offshore platform steels, pressure vessel steels, high quality electrical steels, bearing steels, etc. ${ }^{3-9)}$ Ultra-low-sulphur steels are favored by customers more and more in nowadays because of their excellent comprehensive performance.

The Ruhrstahl-Hausen (RH) treatment has good thermodynamic and kinetic conditions for refining ultra-low-

\footnotetext{
* Corresponding author: E-mail: liguangqiang@wust.edu.cn DOI: http://dx.doi.org/10.2355/isijinternational.ISIJINT-2016-124
}

sulphur steels due to its vacuum condition and circulating flow of liquid steel in the ladle. Because of oxidation atmosphere required for decarburization and reduction atmosphere required for desulphurization, it is necessary for ultra-low-carbon and ultra-low-sulphur steel grades to continue the desulphurization process during $\mathrm{RH}$ refining process directly after decarburization and alloying addition to reduce total treatment time as well as to prevent carbon pick-up. Desulphurization for ultra-low-sulphur steels during $\mathrm{RH}$ process has been studied by many researchers since 1980s. ${ }^{10-19)}$ Sulphur content in the steel was reduced to less than $10 \mathrm{ppm}$ after adding desulphurization powder into $\mathrm{RH}$ vacuum vessel. Knoop et al. ${ }^{11)}$ had reported the results of desulphurization in $320 \mathrm{t}$ ladle after RH treatment by adding $\mathrm{CaO}$ and pre-melt $\mathrm{CaO}-\mathrm{Al}_{2} \mathrm{O}_{3}$ powder which was $1-3 \mathrm{~mm}$ in size through vacuum hopper system at Hoogovens Staal. Their results indicated that sulphur content in the steels was reduced to less than $5 \mathrm{ppm}$ and desulphurization efficiency was improved after powder injection desulphurization in $\mathrm{RH}$ refining process. Desulphurization of liquid steel during RH treatment using $\mathrm{CaO}$-based powder injection through water cooled lance was introduced by Okada et al. ${ }^{15)}$ Sulphur content in $160 \mathrm{t}$ ladle had been reduced from $30 \mathrm{ppm}$ to less than 5 ppm by blowing $\mathrm{CaO}-\mathrm{CaF}_{2}$ powder in size of 0.15 $\mathrm{mm}$ at a rate of $100-130 \mathrm{~kg} / \mathrm{min}$ for $8-12 \mathrm{~min}$, which was applied to produce ultra-low-sulphur steel for sour service 
line pipe and silicon steel. ${ }^{15,16)}$

Although RH refining treatment has been successfully used in producing ultra-low-sulphur steels or ultra-low-carbon steels, there still exist many problems in practical operating process. Sulphur content in the steel can't be controlled stably below 10 ppm for most ultra-low-sulphur steels ${ }^{17-20)}$ because desulphurization conditions haven't been mastered exactly. Because the water model simulation experiment cannot reflect the chemical reaction of desulphurization, it is very difficult to simulate high temperature desulphurization chemical reaction between powder particles and liquid steel in the laboratory scale. Severe wear of RH snorkel and inner vessel refractories in practice also limits its application. In order to clarify the influence of operation conditions on desulphurization kinetics, mathematical models for simulating powder injection desulphurization in $\mathrm{RH}$ were proposed by many researchers. ${ }^{20-23)}$ Wei et al. ${ }^{21)}$ had developed a kinetic model for simulating the desulphurization with $\mathrm{CaO}$-based powder injection and the modeling results were in good agreement with part of results tested in industrial production process. The predicted sulphur content can be decreased to the ultra-low level (5-10) ppm from (60-80) ppm by controlling suitable injection conditions. The deviation between the model calculated results and the tested ones mainly originated from the assumptions which only powder particles had effect on desulphurization and other relative parameters such as sulphur partition ratio $\left(L_{\mathrm{s}}\right)$, temperature of liquid steel, mass transfer coefficient of sulphur were defined as constants. Meanwhile, the effect of ladle top slag on desulphurization and the change of temperature were ignored. $\mathrm{Hu}$ et al. $^{20)}$ pointed out that $L_{\mathrm{s}}$ between powder particles and liquid steel varied during desulphurization processing, and sulphur content in powder particles was changeable at different time, but they also ignored the effect of ladle top slag and temperature variation on desulphurization processing. Zulhan et al. ${ }^{23)}$ improved previous researchers' kinetic model to predict sulphur content during $\mathrm{RH}$ treatment by using Ca-based powder injection. The model was combined with decarburization and alloying addition. Unfortunately, the relationship between temperature and $L_{\mathrm{s}}$, viscosity of liquid steel, mass transfer coefficient of sulphur etc. was not established.

Taking into account kinetic and thermodynamic conditions of desulphurization reaction combining with temperature, composition of slag and liquid steel, $L_{\mathrm{s}}$ changing with practical operating conditions of a steel company, a mathematical model was proposed based on the two-film theory for powder injection desulphurization in $300 \mathrm{t}$ RH processing. Powder injection parameters such as penetrating ratio, average residence time of the powder in the bath and so on are decided by our physical simulation results. Temperature, mass of liquid steel, mass transfer coefficient of sulphur in liquid steel side and top slag side, and other related parameters during desulphurization processing are discussed in the present model. The present model is expected to obtain more accurately simulating results to elucidate mechanism of desulphurization and provide valid guide to practical production of ultra-low-sulphur steels.

\section{Kinetic Model for Powder Injection Desulphuriza- tion during RH Refining Process}

Intensive desulphurization during $\mathrm{RH}$ refining process mainly includes powder particles put into RH vacuum chamber directly and powder particles injected into the bath. RH desulphurization by powder injection has higher contact area between the steel and slag phase, good kinetic conditions of desulphurization reaction by stirring, more homogenizing temperature and chemical composition, more oxygen and carbon removal, etc. In this research, kinetic model of desulphurization during $\mathrm{RH}$ refining process based on the thermodynamic and kinetic principle was developed. In order to predict the concentration changing with time for sulphur accurately, some parameters of these models were optimized by our physical simulation results.

\subsection{Temperature Model for Powder Injection Desul- phurization}

The temperature of liquid steel will change during $\mathrm{RH}$ desulphurization process. Based on heat balance and material balance, the corresponding temperature model was established, which is expected to simulate desulphurization by powder injection in RH process more accurately.

Temperature of liquid steel during desulphurization process in RH is calculated by Eq. (1).

$$
T_{C, t+\Delta t}=T_{P, t}+\frac{\Delta Q}{W_{\mathrm{m}, t} C_{\text {steel }}+W_{\text {slag }, t} C_{\text {slag }}}
$$

Where $T_{P, t}$ is the initial temperature of the liquid steel at a moment $t, \mathrm{~K} ; T_{C, t+\Delta t}$ is the temperature of liquid steel after $\Delta t$ seconds, $\mathrm{K} ; \Delta Q$ is the total heat variation of the bath after $\Delta T$ seconds, $\mathrm{kJ} ; W_{\mathrm{m}, t}$ and $W_{\text {slag, } t}$ are the weight of steel and top slag at the moment $t$, respectively, $\mathrm{kg} ; C_{\text {steel }}$ and $C_{\text {slag }}$ are the specific heat capacity of liquid steel and top slag, respectively, $\mathrm{kJ} \cdot \mathrm{K}^{-1} \cdot \mathrm{kg}^{-1}$.

Vacuum chamber of the simulated RH set should be preheated in waiting station before desulphurization process and the preheating temperature is usually $1473 \mathrm{~K}$. The ladle is often used in other refining process before $\mathrm{RH}$ refining in practical productions. Considering there is a long contact time between ladle refractories and liquid steel, the present model assumes that heat transfer balance between liquid steel and ladle refractories has achieved. Therefore, the effect of ladle refractories on temperature of the liquid steel is ignored. According to the principle of energy conservation, the change of heat energy during $\mathrm{RH}$ refining process can be expressed as Eq. (2):

$$
\Delta Q=Q_{\mathrm{Ar}}+Q_{\mathrm{pow}}+Q_{\mathrm{che}}+Q_{\mathrm{lad}}+Q_{\mathrm{vac}}
$$

Where $Q_{\mathrm{Ar}}$ is heat consumption of driving gas, kJ; $Q_{\text {pow }}$ is heat consumption of injection powder, $\mathrm{kJ} ; Q_{\text {che }}$ is the heat effect of chemical reaction, $\mathrm{kJ}$; $Q_{\text {lad }}$ is heat dissipation of ladle, kJ; $Q_{\text {vac }}$ is the heat storage of vacuum chamber lining, $\mathrm{kJ}$.

\subsection{Kinetic Model Concept for Powder Injection Desulphurization}

Desulphurization reaction during $\mathrm{RH}$ powder injection process contains transitory reaction and permanent contact reaction according to the idea of injection powder metal- 
lurgy. The transitory reaction is the reaction between the injected powders and sulphur in the metal. The permanent contact reaction is the reaction between the top slag and the metal. Desulphurization reaction during $\mathrm{RH}$ process is required to proceed in a strong reduction atmosphere and desulphurization reaction is expressed by reaction (3). The dissolved sulphur in the steel is removed by contact reaction at the interface between liquid steel and molten powders or top slag. According to the two-film theory, the difference of sulphur concentration at each side of the slag-steel interface is the driving force of desulphurization.

Desulphurization reaction usually takes place at about $1873 \mathrm{~K}$. Desulphurization reaction process is a high temperature metallurgy process and chemical reaction rate is very fast. Thus, chemical reaction can't be the rate-limiting step. The rate-limiting step is the transfer of [S] from liquid steel towards the slag-steel interface ${ }^{17,24)}$ or $\left(\mathrm{S}^{2-}\right)$ from the slag or injected powders towards the interface. ${ }^{25-28)}$

$$
3[\mathrm{~S}]+2[\mathrm{Al}]+3(\mathrm{CaO})=3(\mathrm{CaS})+\left(\mathrm{Al}_{2} \mathrm{O}_{3}\right)
$$

In order to simplify the model and calculation, following assumptions are made for the present desulphurization mathematical model:

(1) The rate of powder injection remains constant during the process, spherical powder particles injected into the molten bath has uniform size and melted. The aggregation and collision of the powder particles are ignored and the number of particles is assumed to remain unchanged. The concentration of elements in liquid steel is approximated constant and $\mathrm{CaF}_{2}$ in the powder particles does not participate in desulphurization reaction under the process of powder floating into the top slag. Amount and composition of the top slag are time-dependent and are determined by the initial composition of the top slag and powder injection rate.

(2) Transitory desulphurization reaction continues until powder particles break steel-slag interface into the top slag. Not only powder particles but also top slag are not volatile and solute in the liquid steel.

(3) Concentration gradient only exists near the interface of phase boundary and the composition of the steel is uniform due to good mixing characteristics of liquid steel in $\mathrm{RH}$ refining process. The vacuum chamber without initial slag and liquid steel has been fully purged with argon gas before RH treatment to get a low level of oxygen.

(4) Chemicals react very quickly under high temperature, and the chemical reaction at the steel-slag interface reaches equilibrium so that chemical reaction can't be the rate-determining step for desulphurization kinetics. Both transitory sulfur removal rate of the powder particles and permanent sulfur removal rate of the ladle top slag are contribute to the total sulfur removal rate during $\mathrm{RH}$ desulphurization process, which is expressed in Eq. (4) using sulphur concentration change in liquid steel.

$$
J_{[\mathrm{S}]}=J_{[\mathrm{S}]}^{\mathrm{T}}+J_{[\mathrm{S}]}^{\mathrm{P}}
$$

Where $J_{[\mathrm{S}]}, J_{[\mathrm{S}]}^{\mathrm{T}}$ and $J_{[\mathrm{S}]}^{\mathrm{P}}$ are the mass transfer rate of sulphur in liquid steel, transitory contact reaction zone and permanent contact reaction zone, $\mathrm{mol} /\left(\mathrm{m}^{2} \cdot \mathrm{s}\right)$, respectively.

\subsubsection{Transitory Reaction Sulfur Removal Rate of Powder Particles}

Based on the above assumptions, the effect of mixing time on the desulphurization after the powder particles injected into the molten pool is considered in the present model which is often overlooked in other models. According to two-film theory, ${ }^{22)}$ the sulfur removal rate can be described by Eq. (5). ${ }^{29)}$ The mass transfer coefficient of sulphur in the transitory reaction zone is calculated by Eq. (6).

$$
\begin{aligned}
& J_{[\mathrm{S}]}^{\mathrm{T}}=-\frac{\mathrm{d} w[\mathrm{~S}]}{\mathrm{d} t}=\frac{A_{\mathrm{s}-\mathrm{m}}^{\mathrm{T}}}{W_{\mathrm{m}, t}} \cdot \rho_{\mathrm{m}} \cdot k_{\mathrm{S}}^{\mathrm{T}} \cdot \frac{\tau_{\mathrm{B}}}{\tau_{\mathrm{B}}+\tau_{\mathrm{m}}}\left(w[\mathrm{~S}]-\frac{w(\mathrm{~S})_{\mathrm{T}}}{L_{\mathrm{ST}}}\right) \\
& k_{\mathrm{S}}^{\mathrm{T}}=\frac{k_{[\mathrm{S}]}^{\mathrm{T}} L_{\mathrm{ST}}}{k_{[\mathrm{S}]}^{\mathrm{T}} \rho_{\mathrm{m}} /\left(k_{(\mathrm{S})}^{\mathrm{T}} \rho_{\mathrm{p}}\right)+L_{\mathrm{ST}}}
\end{aligned}
$$

Where $w[\mathrm{~S}]$ is the mass fraction of sulphur in liquid steel, $\% ; w(\mathrm{~S})_{\mathrm{T}}$ is the mass fraction of sulphur in powder particles, $\% ; A_{\mathrm{s}-\mathrm{m}}^{\mathrm{T}}$ is the interfacial area between powder particles and liquid steel, $\mathrm{m}^{2} ; W_{\mathrm{m}, \mathrm{t}}$ is the quantity of liquid steel, $\mathrm{kg} ; k_{\mathrm{S}}^{\mathrm{T}}$ is the overall mass transfer coefficient of sulphur in the transitory reaction zone, $\mathrm{m} \cdot \mathrm{s}^{-1} ; k_{[\mathrm{S}]}^{\mathrm{T}}, k_{(\mathrm{S})}^{\mathrm{T}}$ is the mass transfer coefficient of sulphur in liquid steel side and powder particles side, $\mathrm{m} \cdot \mathrm{s}^{-1} ; L_{\mathrm{ST}}$ is the sulphur partition ratio between powder particles and liquid steel; $\rho_{\mathrm{p}}, \rho_{\mathrm{m}}$ is the density of powder particles and liquid steel, $\mathrm{kg} \cdot \mathrm{m}^{-3} ; \tau_{\mathrm{m}}$ is the mixing time of powder particles in molten pool, $\mathrm{s} ; \tau_{\mathrm{B}}$ is the total time of powder injection, s.

Relevant parameters used in the transitory reaction can be calculated as Eqs. (7) to (13):

$$
\begin{aligned}
& A_{\mathrm{s}-\mathrm{m}}^{\mathrm{T}}=\left(\beta \cdot I_{\mathrm{P}} \cdot \tau_{\mathrm{R}}\right) /\left(10 \rho_{\mathrm{P}} \cdot d_{\mathrm{P}}\right) \\
& k_{[\mathrm{S}]}^{\mathrm{T}}=\left[2+0.6\left(u_{\mathrm{r}} \rho_{\mathrm{m}} d_{\mathrm{p}} / \eta_{[\mathrm{S}]}^{\mathrm{T}}\right)^{1 / 2}\left(\eta_{[\mathrm{S}]}^{\mathrm{T}} / \rho_{\mathrm{m}} D_{[\mathrm{S}]}^{\mathrm{T}}\right)^{1 / 3}\right] / D_{[\mathrm{S}]}^{\mathrm{T}} d_{\mathrm{p}}{ }^{29)} \\
& u_{\mathrm{r}} \approx u_{1}+u_{\mathrm{P}} \\
& u_{\mathrm{p}}=\left(\rho_{\mathrm{m}}-\rho_{\mathrm{p}}\right) g d_{\mathrm{p}}^{2} /\left(18 \eta_{[\mathrm{S}]}^{\mathrm{T}}\right)^{29)} \\
& D_{[\mathrm{S}]}^{\mathrm{T}}=D_{0} \exp \left(-E_{\mathrm{D}} / \mathrm{R} T\right)^{30)} \\
& \eta_{[\mathrm{S}]}^{\mathrm{T}}=\eta_{0} \exp \left(E_{\eta} / \mathrm{R} T\right)^{30)} \\
& k_{(\mathrm{S})}^{\mathrm{T}}=\left(2 \pi^{2} D_{(\mathrm{S})}^{\mathrm{T}} / 3 d_{\mathrm{P}}\right)^{31)}
\end{aligned}
$$

Where $\tau_{\mathrm{R}}$ is the average residence time of powder particles in the liquid steel, $\mathrm{s} ; \beta$ is the penetration ratio of powder particles, $\%$; $d_{\mathrm{p}}$ is the average diameter of powder particles, $\mathrm{m} ; D_{[\mathrm{S}]}^{\mathrm{T}}, D_{(\mathrm{S})}^{\mathrm{T}}$ is the diffusion coefficient of sulphur in liquid steel side and powder particles side, $\mathrm{m}^{2} \cdot \mathrm{s}^{-1} ; u_{\mathrm{p}}$ is the floating velocity of powder particles, $\mathrm{m} \cdot \mathrm{s}^{-1} ; u_{1}$ is the circulation velocity of liquid steel, $\mathrm{m} \cdot \mathrm{s}^{-1} ; u_{\mathrm{r}}$ is the relative velocity of liquid steel and powder particles, $\mathrm{m} \cdot \mathrm{s}^{-1} ; \eta_{[\mathrm{S}]}^{\mathrm{T}}$ is the viscosity of liquid steel, Pa.s. $D_{0}$ is $4.33 \times 10^{-8} \mathrm{~m}^{2} \cdot \mathrm{s}^{-1}$, $E_{\mathrm{D}}$ is $35.60 \times 10^{3} \mathrm{~J} \cdot \mathrm{mol}^{-1}, \eta_{0}$ is $0.31 \times 10^{-3} \mathrm{~Pa} \cdot \mathrm{s}, E_{\eta}$ is $43.94 \times 10^{3} \mathrm{~J} \cdot \mathrm{mol}^{-1}$, and $D_{(\mathrm{S})}^{\mathrm{T}}$ is $9.50 \times 10^{-10} \mathrm{~m}^{2} \cdot \mathrm{s}^{-1}$ in the above formula.

$L_{\mathrm{ST}}$ is calculated by experiential formula based on $\mathrm{CaO}-$ $\mathrm{CaF}_{2}$ powder particles injection published by Komai. ${ }^{32}$ $\beta$ and $\tau_{\mathrm{m}}$ are determined according to the related physical 
simulating results after proceeding in the same scale RH set and operating conditions tested by the present authors. According to the reaction (3), the quantity of liquid steel and top slag will be changed with the migration of sulphur and aluminum.

2.2.2. Permanent Reaction Sulfur Removal Rate of Ladle Top Slag

Sulfur removal rate between top slag and liquid steel can be calculated by Eq. (14).

$$
\begin{gathered}
J_{[\mathrm{S}]}^{\mathrm{P}}=-\frac{d w[\mathrm{~S}]}{d t}=\frac{A_{\mathrm{s}-\mathrm{m}}^{\mathrm{P}}}{W_{\mathrm{m}, t}} \cdot \rho_{\mathrm{m}} \cdot k_{\mathrm{S}}^{\mathrm{P}} \cdot\left(w[\mathrm{~S}]-\frac{w(\mathrm{~S})_{\mathrm{P}}}{L_{\mathrm{SP}}}\right) \ldots \\
k_{\mathrm{S}}^{\mathrm{P}}=\frac{k_{\mathrm{S}]}^{\mathrm{T}} L_{\mathrm{SP}}}{k_{[\mathrm{S}]}^{\mathrm{T}} \rho_{\mathrm{m}} /\left(k_{(\mathrm{S})}^{\mathrm{P}} \rho_{\mathrm{S}}\right)+L_{\mathrm{SP}}} \ldots \ldots \ldots \ldots \ldots \ldots \ldots \ldots \ldots
\end{gathered}
$$

Where $w(\mathrm{~S})_{\mathrm{P}}$ is the mass fraction of sulphur in top slag, $\% ; A_{\mathrm{S}-\mathrm{M}}^{\mathrm{P}}$ is the interfacial area between top slag and liquid steel, $\mathrm{m}^{2} ; k_{\mathrm{S}}^{\mathrm{P}}$ is the overall mass transfer coefficient of sulphur in the permanent reaction zone, $\mathrm{m} \cdot \mathrm{s}^{-1} ; k_{(\mathrm{S})}^{\mathrm{P}}$ is the mass transfer coefficient of sulphur in top slag side, $\mathrm{m} \cdot \mathrm{s}^{-1} ; L_{\mathrm{SP}}$ is the sulphur partition ratio between top slag and liquid steel; $\rho_{\mathrm{s}}$ is the density of top slag, $\mathrm{kg} \cdot \mathrm{m}^{-3}$.

Relevant parameters used in the permanent reaction can be calculated by Eqs. (16) to (19):

$$
\begin{aligned}
& k_{(\mathrm{S})}^{\mathrm{P}}=0.664\left(\rho_{\mathrm{S}} H_{\mathrm{S}} V_{0} / \eta_{(\mathrm{S})}^{\mathrm{p}}\right)^{1 / 2}\left(\eta_{(\mathrm{S})}^{\mathrm{p}} / \rho_{\mathrm{S}} D_{(\mathrm{S})}^{\mathrm{p}}\right)^{1 / 3} D_{(\mathrm{S})}^{\mathrm{p}} / H_{\mathrm{s}}{ }^{29)} \\
& D_{(\mathrm{S})}^{\mathrm{P}}=D_{0} \exp \left(-E_{\mathrm{D}} / \mathrm{R} T\right)^{30)} \\
& \eta_{(\mathrm{S})}^{\mathrm{p}}=\eta_{0} \exp \left(E_{\eta} / \mathrm{R} T\right)^{30)} \\
& \lg L_{\mathrm{SP}}=-935 / T+1.375+\lg f_{[\mathrm{S}]}+\lg C_{\mathrm{S}}-\lg a_{[\mathrm{O}]}{ }^{33)}
\end{aligned}
$$

Where $D_{(\mathrm{S})}^{\mathrm{P}}$ is the diffusion coefficient of sulphur in top slag, $\mathrm{m}^{2} \cdot \mathrm{s}^{-1} ; H_{\mathrm{s}}$ is the thickness of top slag, $\mathrm{m} ; V_{0}$ is the relative velocity of liquid steel and top slag, $\mathrm{m} \cdot \mathrm{s}^{-1} ; \eta_{(\mathrm{S})}^{\mathrm{P}}$ is the viscosity of top slag, Pa.s. $D_{0}$ is $1.40 \times 10^{-4} \mathrm{~m}^{2} \cdot \mathrm{s}^{-1}$, $E_{\mathrm{D}}$ is $205.02 \times 10^{3} \mathrm{~J} \cdot \mathrm{mol}^{-1}, \eta_{0}$ is $8.00 \times 10^{-9} \mathrm{~Pa} \cdot \mathrm{s}$, and $E_{\eta}$ is $258.21 \times 10^{-3} \mathrm{~J} \cdot \mathrm{mol}^{-1}$ in the above formula. $C_{\mathrm{S}}$ is the sulphide capacity and calculated by the optical basicity; ${ }^{34)}$ $f_{[\mathrm{s}]}$ is the activity coefficient of sulphur in liquid steel and calculated by the Wagner's Eq. (20). ${ }^{35)} a_{[\mathrm{O}]}$ is the activity of oxygen and calculated by Eq. (23) according to aluminum deoxidation reaction (21) and the equilibrium constant of reaction (21) by Eq. (22). ${ }^{36)}$ And parameters such as $f_{[\mathrm{s}]}$,
$f_{[\mathrm{Al}]}, C_{\mathrm{S}}, a_{[\mathrm{O}]}$ are determined using data in Tables 1, 2 and $\mathbf{3}$, respectively.

$$
\begin{array}{r}
\lg f_{[\mathrm{i}]}=\sum\left(e_{\mathrm{i}}^{\mathrm{j}} \cdot w[\mathrm{j}]\right) \ldots \ldots \ldots \ldots \ldots \ldots \ldots \\
2[\mathrm{Al}]+3[\mathrm{O}]=\left(\mathrm{Al}_{2} \mathrm{O}_{3}\right) \ldots \ldots \ldots \ldots \ldots \ldots \ldots \ldots \ldots \ldots \ldots \ldots \\
\lg K=\lg \frac{a_{\left(\mathrm{Al}_{2} \mathrm{O}_{3}\right)}}{a_{[\mathrm{Al}]}^{2} \cdot a_{[\mathrm{O}]}^{3}}=\frac{45300}{T}-11.62 \ldots \ldots \ldots \ldots \\
\lg a_{[\mathrm{O}]}=\frac{1}{3} \lg a_{\left(\mathrm{Al}_{2} \mathrm{O}_{3}\right)}-\frac{2}{3} \lg f_{[\mathrm{Al}]}-\frac{2}{3} \lg w[\mathrm{Al}]-\frac{15100}{T}+3.87
\end{array}
$$

\subsection{Calculation Process of the Model}

The present kinetic model is developed based on the production conditions of $300 \mathrm{t} \mathrm{RH}$ device in a steel company. According to the sulfur removal rate equations and the practical production parameters in Table 4, calculation programs are established by using MATLAB software. ${ }^{38,39)}$ Time step is 1 second, and iterative method is used to calculate parameters at every moment in the model after inputting basic operating parameters in Table 4, the initial composition of top slag in Table 1, the initial composition of steel in Table 2. The flow chart of model calculation is shown in Fig. 1. $\eta_{[\mathrm{s}]}$ is desulphurization ratio. Penetration ratio of powder particles $\beta$ is powder particles injected into the bath, the average residence time of powder particles $\tau_{\mathrm{R}}$ is the average time of powder particles floating up to steelslag interface, and the mixing time of powder particles $\tau_{\mathrm{m}}$ is the time of powder particles uniformly distributed in the molten bath.

\section{Model Validations}

In order to validate the proposed model, experiments conducted by $\mathrm{Hu}$ et al. $^{20)}$ about desulphurization refining process in a $300 \mathrm{t} \mathrm{RH}$ device with powder being added through an alloy chute to the vacuum chamber are used to prove numerical simulation results. The results both $\mathrm{Hu}$ et al. reported and the present model calculated at the same operation conditions are shown in Fig. 2. The results indicate that

Table 1. Initial chemical composition of top slag before RH refining $/ \%$.

\begin{tabular}{cccccc}
\hline $\mathrm{CaO}$ & $\mathrm{SiO}_{2}$ & $\mathrm{Al}_{2} \mathrm{O}_{3}$ & $\mathrm{MgO}$ & $\mathrm{FeO}$ & $\mathrm{MnO}$ \\
\hline 50 & 10 & 30 & 5 & 2 & 0.5 \\
\hline
\end{tabular}

Table 2. Chemical composition of liquid steel before $\mathrm{RH}$ refining/\%.

\begin{tabular}{cccccccccccc}
\hline $\mathrm{C}$ & $\mathrm{Si}$ & $\mathrm{Mn}$ & $\mathrm{P}$ & $\mathrm{Al}$ & $\mathrm{Ni}$ & $\mathrm{Mo}$ & $\mathrm{Cu}$ & $\mathrm{Nb}$ & $\mathrm{V}$ & $\mathrm{Ti}$ & $\mathrm{Fe}$ \\
\hline 0.04 & 0.25 & 1.65 & 0.006 & 0.048 & 0.30 & 0.21 & 0.22 & 0.067 & 0.023 & 0.013 & Bal. \\
\hline
\end{tabular}

Table 3. Interaction coefficients of elements in liquid steel at $1873 \mathrm{~K}^{37}$ )

\begin{tabular}{cccccccccccc}
\hline$i$ & $e_{i}^{\mathrm{C}}$ & $e_{i}^{\mathrm{Si}}$ & $e_{i}^{\mathrm{Mn}}$ & $e_{i}^{\mathrm{P}}$ & $e_{i}^{\mathrm{Al}}$ & $e_{i}^{\mathrm{Ni}}$ & $e_{i}^{\mathrm{Mo}}$ & $e_{i}^{\mathrm{Cu}}$ & $e_{i}^{\mathrm{Nb}}$ & $e_{i}^{\mathrm{V}}$ & $e_{i}^{\mathrm{Ti}}$ \\
\hline $\mathrm{S}$ & 0.113 & 0.063 & -0.026 & 0.029 & 0.035 & 0 & 0.0027 & -0.0084 & -0.013 & -0.016 & -0.072 \\
$\mathrm{Al}$ & 0.091 & 0.0056 & 0 & 0 & 0.045 & 0 & 0 & 0.006 & 0 & 0 & 0 \\
\hline
\end{tabular}


the lowest sulphur content calculated by the model is lower than that of industrial experimental tested under the same conditions and the tendency of sulphur content changed in the liquid steel is the same. Because the powder particles were put into the bath directly instead of injection and they cannot be spread evenly and mixed entirely in the bath which decreases the contact area between powder particles and liquid steel at the same time, the sulfur removal rate is lower than that of calculated results which adds powder particles by injection. The difference between numerical simulation and experimental results reduces with the increase of treating time when powder particles are mixed more evenly in the liquid steel. And the results become closer in the late

Table 4. Parameters used in model calculation.

\begin{tabular}{|c|c|}
\hline Parameters & value \\
\hline Treated steel weight in $\mathrm{RH}$ process $C, \mathrm{t}$ & 300 \\
\hline Top lance height $H, \mathrm{~m}$ & 2 \\
\hline Top lance gas flow $Q_{\mathrm{t}}, \mathrm{Nm}^{3} / \mathrm{h}$ & 400 \\
\hline Initial top slag thickness $H_{\mathrm{s}}, \mathrm{m}$ & 0.1 \\
\hline Liquid steel height in vacuum chamber $H_{\mathrm{lv}}, \mathrm{m}$ & 0.4 \\
\hline Powder compositions, $\%$ & $\sim\left(75 \% \mathrm{CaO}-25 \% \mathrm{CaF}_{2}\right)$ \\
\hline Average diameter of powder particles $d_{\mathrm{p}}, \mathrm{mm}$ & $0.15-1$ \\
\hline Powder injection rate $I_{\mathrm{p}}, \mathrm{kg} / \mathrm{min}$ & $150-300$ \\
\hline Driving gas flow $Q_{\mathrm{d}}, \mathrm{Nm}^{3} / \mathrm{h}$ & $\sim 130$ \\
\hline Density of liquid steel $\rho_{\mathrm{m}}, \mathrm{kg} / \mathrm{m}^{3}$ & 7200 \\
\hline Density of powder particles $\rho_{\mathrm{p}}, \mathrm{kg} / \mathrm{m}^{3}$ & 3300 \\
\hline Density of top slag $\rho_{\mathrm{s}}, \mathrm{kg} / \mathrm{m}^{3}$ & 3200 \\
\hline Time step $\Delta t, \mathrm{~s}$ & 1 \\
\hline Total time of powder injection $\tau_{\mathrm{B}}$, min & 10 \\
\hline Initial temperature of liquid steel $T_{0}, \mathrm{~K}$ & 1873 \\
\hline Powder penetration ratio $\beta, \%(0.35-1) \mathrm{mm}$ & 97 \\
\hline$\beta, \%(0.15-0.30) \mathrm{mm}$ & $415 \cdot d^{2}-46.5 \cdot d_{p}+49.8$ \\
\hline Mixing time $\tau_{\mathrm{m}}, \mathrm{s}$ & 53 \\
\hline Average residence time of powders $\tau_{\mathrm{R}}, \mathrm{s}$ & 180 \\
\hline
\end{tabular}

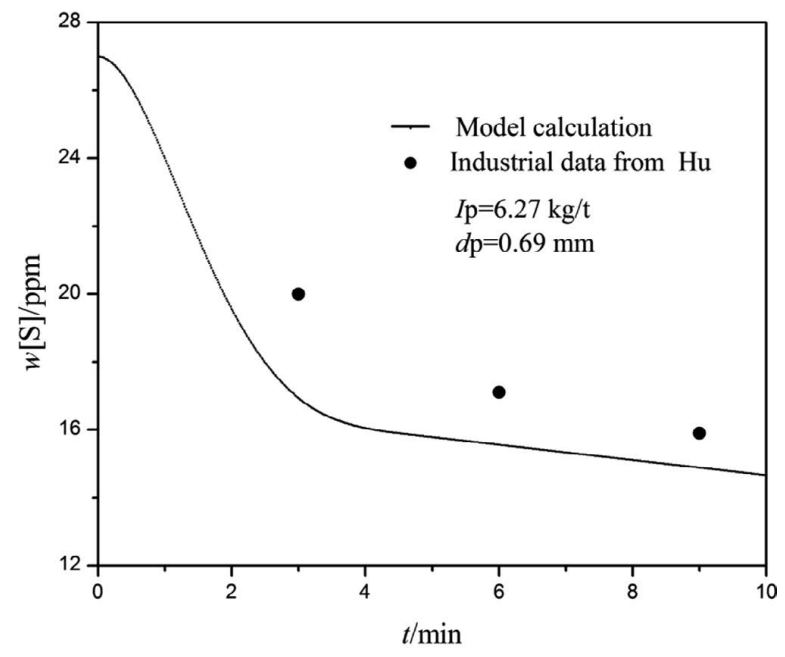

(a) period of desulphurization process. The simulated results indicate that the present model can be used for predicting the effect of operation conditions on desulphurization process and provide guidance to select reasonable production

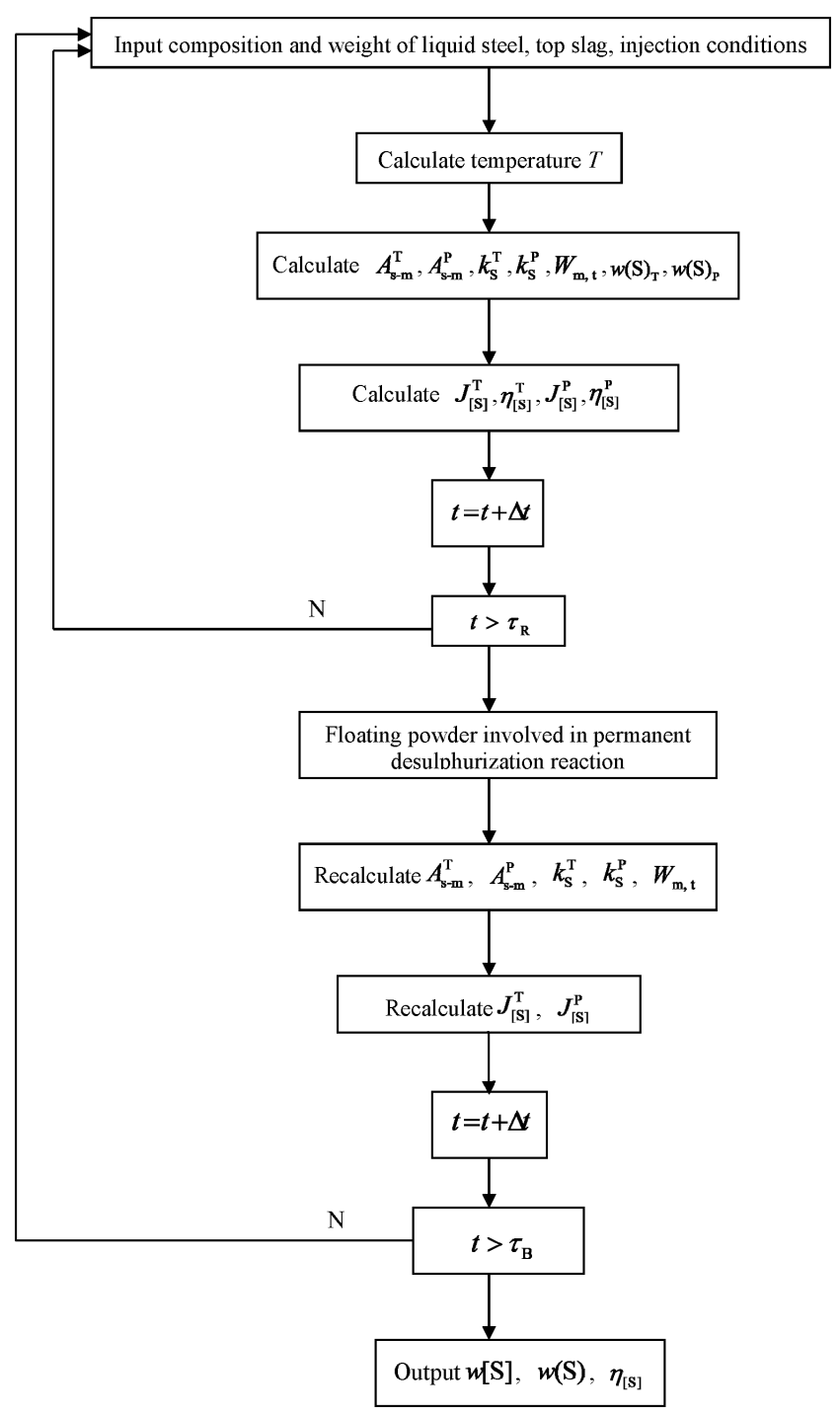

Fig. 1. Flow chart of model calculation.

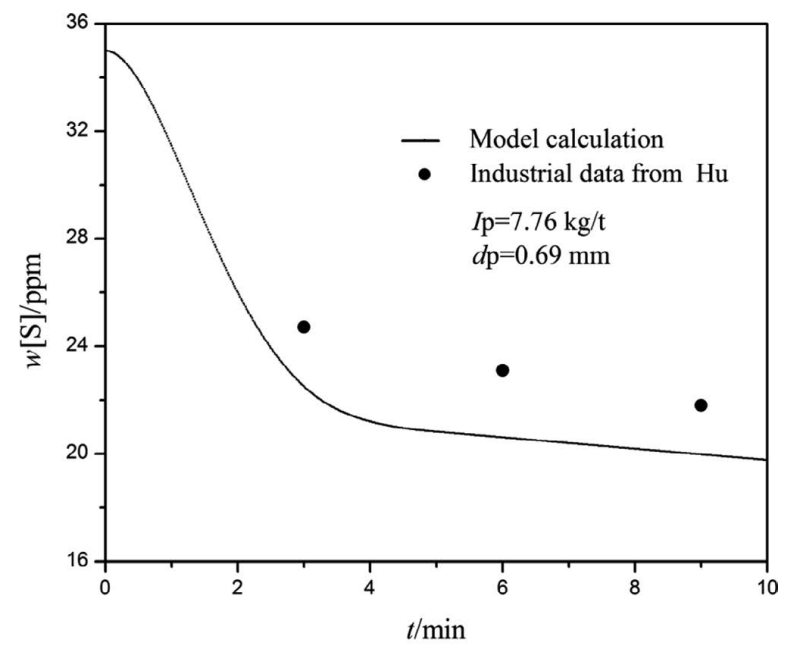

(b)

Fig. 2. The calculated results compared with industrial experimental results reported by Hu et al. ${ }^{20)}$ 
technological parameters for steelmaking.

In order to validate the popularity of the proposed model applied in RH powder injection refining process, the calculated results based on the device and operation conditions reported by Okano et al. ${ }^{16)}$ are compared with their industrial experimental results in Fig. 3. Okano et al. reported the production results on desulphurization of molten steel during $\mathrm{RH}$-treatment using $\mathrm{CaO}-\mathrm{CaF}_{2}$ based flux injection adopting top blowing method. Sulphur content in $160 \mathrm{t}$ ladle reduced from $30 \mathrm{ppm}$ to less than $5 \mathrm{ppm}$ by blowing particles of which the diameter was $0.15 \mathrm{~mm}$ and the powder injection rate was $100-130 \mathrm{~kg} / \mathrm{min}$ after treating $8-10 \mathrm{~min}$. When the calculating conditions are the same as above in the present model, the change tendency of the calculated sulphur content in liquid steel is in accordance with the industrial data reported by Okano et al. under different initial sulphur content level in the liquid steel although there is a little deviation with each other in the first half of the desulphurization reaction. Due to the average residence time of powder particles in liquid steel is different between model calculation and Okano et al. under different level of driving gas, there occurred some differences in the level of sulphur content in the second half of the desulphurization reaction. The compared results indicate that the proposed model can be used to simulate $\mathrm{RH}$ powder injection process when the initial sulphur content decreases to a relative lower level.

\section{Results and Discussion}

\subsection{Effect of Initial Sulphur Content and Operation Conditions on Temperature Drop}

Figure 4 shows the effect of initial sulphur content on temperature drop in the bath. The initial sulphur content in the steel is low and its influence on heat effect of chemical reaction of desulphurization is so slightly that the temperature drop in the bath only increases $0.08 \mathrm{~K}$ when initial sulphur content varies from $25 \mathrm{ppm}$ to $45 \mathrm{ppm}$. The temperature drop during $\mathrm{RH}$ treatment is $12.38 \mathrm{~K}$ after refining $10 \mathrm{~min}$ without powder injection, and the average temperature drop rate is about $1.24 \mathrm{~K} / \mathrm{min}$ which is similar to that reported by Liu, ${ }^{40)}$ which the average temperature drop rate

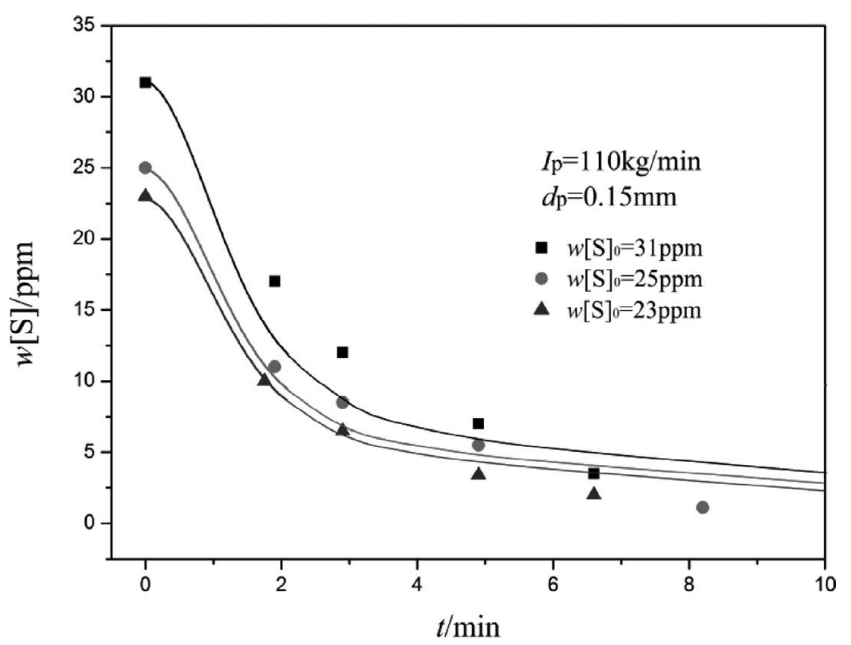

Fig. 3. The calculated results compared with experimental results of $\mathrm{RH}$ powder injection desulphurization reported by Okano. $^{16)}$ is $(0.7-1.3) \mathrm{K} / \mathrm{min}$ in traditional $300 \mathrm{t} \mathrm{RH}$ treatment device.

The effect of powder injection rate on temperature drop is shown in Fig. 5. The effect of powder injection rate on temperature drop is obviously due to that powder injection rate changes the quantities of materials added in the bath which leads to heat effect being changed. The calculated results indicate that the temperature drop increases $7.73 \mathrm{~K}$ when powder injection rate varies from $150 \mathrm{~kg} / \mathrm{min}$ to $300 \mathrm{~kg} / \mathrm{min}$.

The effect of initial temperature of the treated steel in the bath on temperature drop is shown in Fig. 6. The calculated results show that the temperature drop only decreases 3.36 $\mathrm{K}$ when the initial temperature varies from $1873 \mathrm{~K}$ to 1773 $\mathrm{K}$. When heat preservation situation of the bath is excellent and the operation conditions are stable in the desulphurization process, the temperature drop can be ignored.

The calculated results indicated that the effect of powder particles diameter on temperature drop is also small, and the temperature drop decreases $0.12 \mathrm{~K}$ when powder diameter decreases from $0.8 \mathrm{~mm}$ to $0.4 \mathrm{~mm}$. The effect of driving gas flow on temperature drop is more less and the temperature drop increases only $0.02 \mathrm{~K}$ when driving gas varies from 90 $\mathrm{Nm}^{3} / \mathrm{h}$ to $130 \mathrm{Nm}^{3} / \mathrm{h}$.

From the above predicted results, the effect of initial

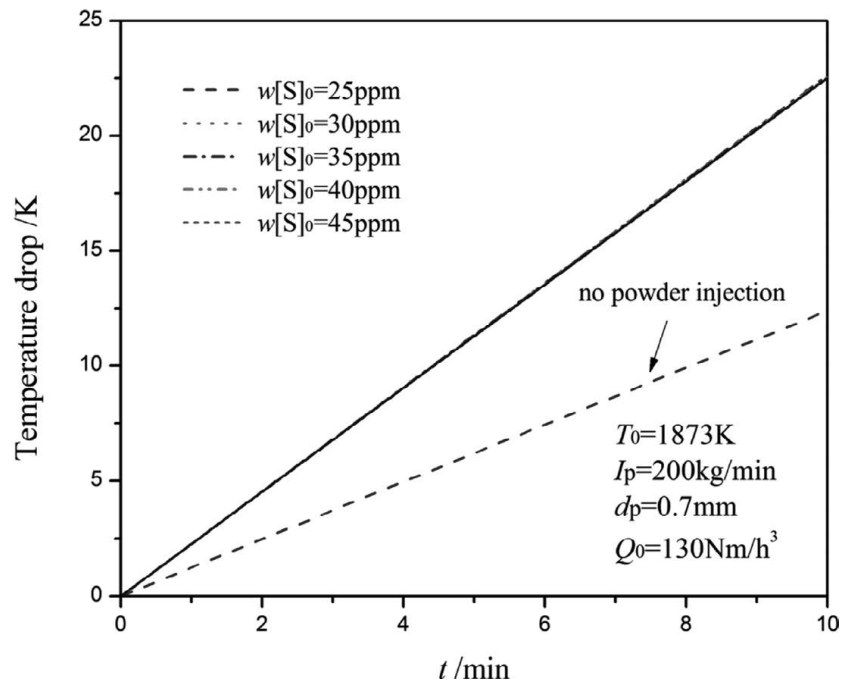

Fig. 4. Effect of initial sulphur content on temperature drop.

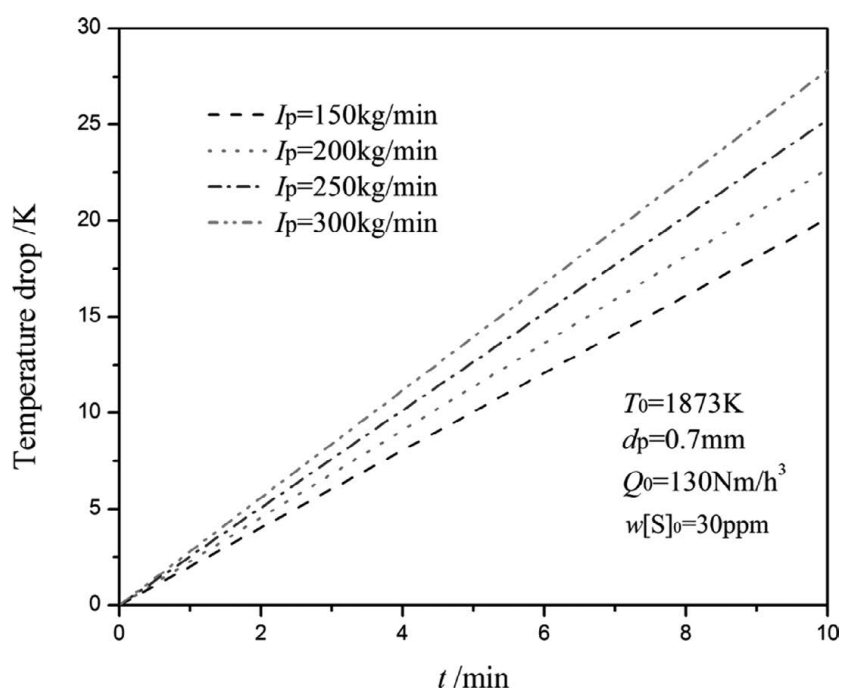

Fig. 5. Effect of powder injection on temperature drop. 


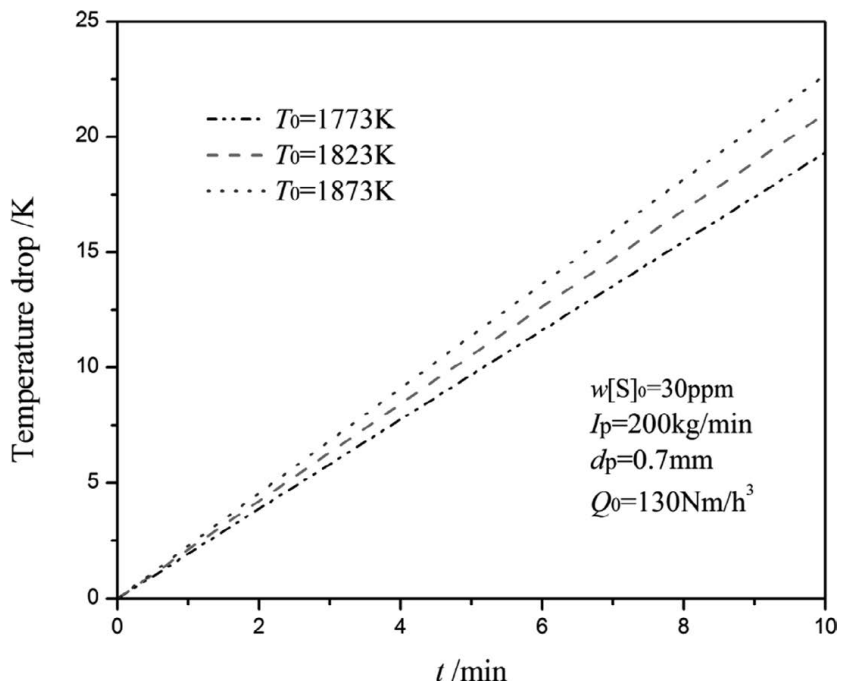

Fig. 6. Effect of initial temperature on temperature drop.

sulphur content and operation conditions on temperature drop is limited which indicates temperature drop has a little effect on desulphurization. Optimizing and stabilizing operation conditions are the key to improve desulphurization efficiency.

\subsection{Contribution Ratio of Transitory Reaction}

The effect of initial sulphur content in top slag on the contribution ratio of transitory reaction is shown in Table 5. The contribution ratio of transitory reaction is maintained at more than $98.52 \%$ and increases with increase of initial sulphur content in top slag from 0 to $0.12 \%$ after BOF. Except a few part of powder particles escape with gas in vacuum chamber, most powder particles are directly involved in the transitory desulphurization reaction during $\mathrm{RH}$ desulphurization process. Compared with the permanent reaction, transitory reaction boundary area is larger and desulphurization reaction proceeding more intensely, which plays a major role in the total desulphurization reaction. Equation (14) indicates that $\left(w[\mathrm{~S}]-w(\mathrm{~S})_{\mathrm{P}} / L_{\mathrm{SP}}\right)$ will reduce with increasing initial sulphur content in the top slag, the contribution rate of permanent reaction decreases and then the ratio of transitory reaction increases.

\subsection{Effect of Initial Sulphur Content on Desulphuriza- tion Process}

The effects of initial sulphur content in liquid steel on desulphurization process and desulphurization ratio are shown in Figs. 7 and 8. Figure 7 depicts the sulfur removal rate increases dramatically and reaches the maximum sulfur removal rate after about $1.8 \mathrm{~min}$ of the injection of powder particles. Then, the concentration of sulphur between liquid steel and powder particles reduces with the gradual accumulation of sulphur in powder particles, and the sulfur removal rate reduces. After $3 \mathrm{~min}$, the sulfur removal rate decreases further with the time of powder particles floating into steel-slag interface and the concentration of sulphur between liquid steel and powder particles reduces. The desulphurization ratio is slightly increased with increasing initial sulphur content in the liquid steel (see Fig. 8). In order to obtain lower final sulphur content in the liquid steel after RH refining under the same conditions, hot metal
Table 5. Contribution ratio of transitory reaction

\begin{tabular}{cccccccc}
\hline $\begin{array}{c}\text { Top slag } \\
w(\mathrm{~S})_{\mathrm{P} 0} \%\end{array}$ & 0 & 0.02 & 0.04 & 0.06 & 0.08 & 0.1 & $>0.12$ \\
\hline $\begin{array}{c}\text { Contribution } \\
\text { ratio\% }\end{array}$ & 98.52 & 98.59 & 98.66 & 98.73 & 98.79 & 98.85 & $>98.91$ \\
\hline
\end{tabular}

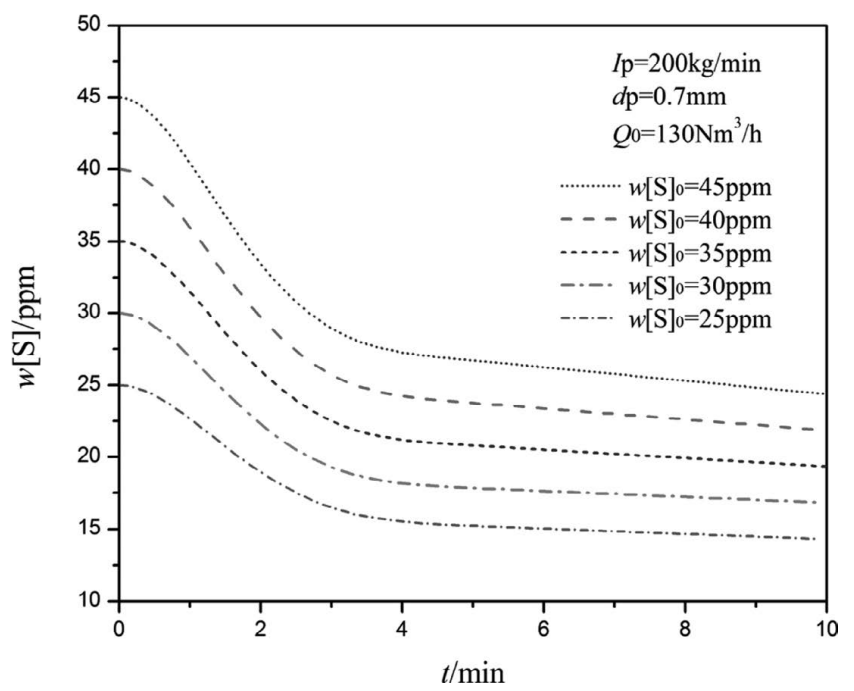

Fig. 7. Effect of initial sulphur content on desulphurization process.

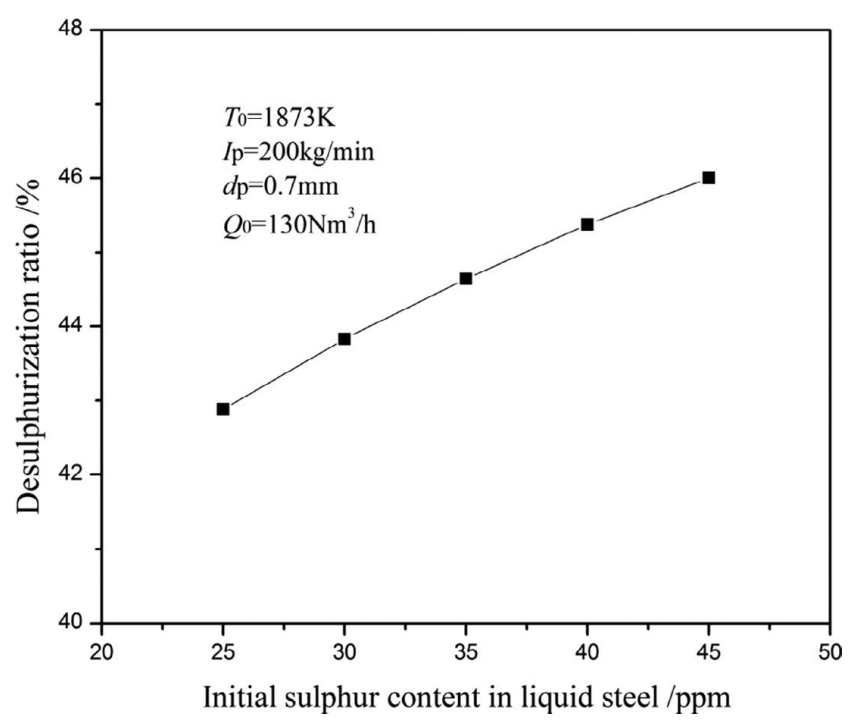

Fig. 8. Effect of initial sulphur content on desulphurization ratio.

pretreatment should be carried out and sulphur content in the steel after BOF should be controlled to make sure a lower initial sulphur content in the liquid steel for RH refining.

\subsection{Effect of Powder Injection Rate on Desulphuriza- tion Process}

The effect of powder injection rate on desulphurization process and desulphurization ratio are shown in Figs. 9 and 10. As shown in Fig. 9, the sulfur removal rate of liquid steel improves obviously with the increase of the powder injection rate. The reaction area of transitory desulphurization process increases with the increase of the powder injection rate, which is conducive to the desulphurization reaction. The change of sulphur content in the liquid steel is $1.71 \mathrm{ppm}, 1.39 \mathrm{ppm}, 1.18 \mathrm{ppm}$ when powder injection 


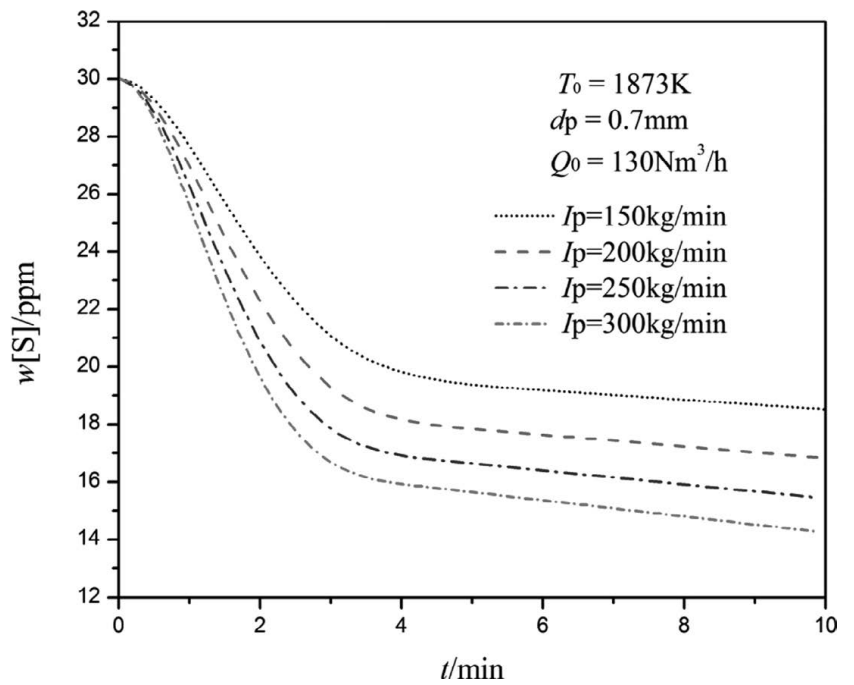

Fig. 9. Effect of powder injection rate on desulphurization process.

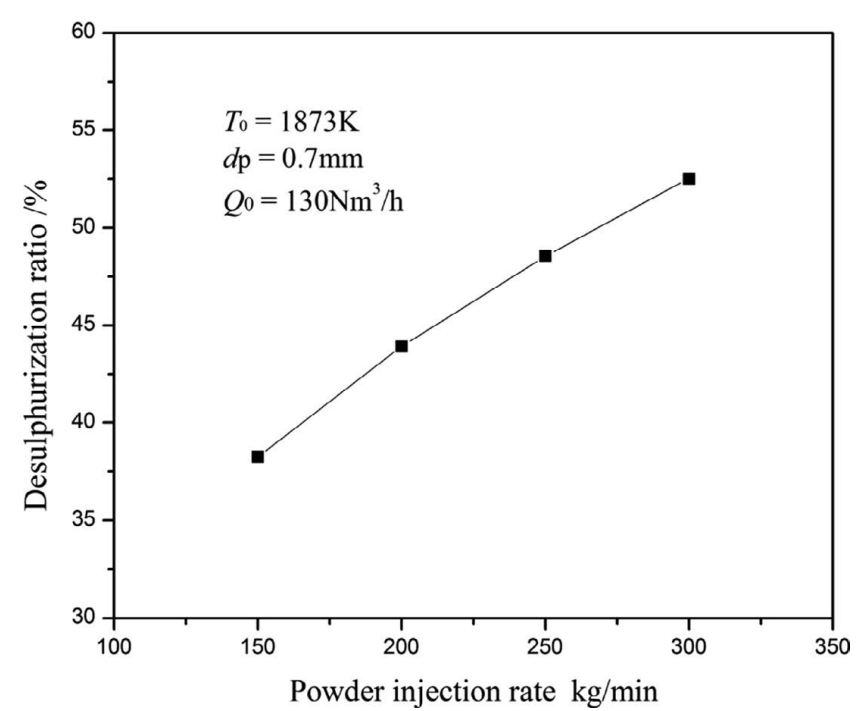

Fig. 10. Effect of powder injection rate on desulphurization ratio.

rate varies from $(150-200) \mathrm{kg} / \mathrm{min}$ to $(200-250) \mathrm{kg} / \mathrm{min}$ and then to $(250-300) \mathrm{kg} / \mathrm{min}$, respectively, after treating $10 \mathrm{~min}$. Figure 10 illustrates the desulphurization ratio is increased with the increase of powder injection rate and presents a decreasing trend. Since the powder injection rate infects significantly on decrease of sulphur content in the liquid steel, the recommended powder injection rate is in the range of (250-300) kg/min.

\subsection{Effect of Powder Particles Diameter on Desul- phurization Process}

The effect of powder particles diameter on desulphurization process and desulphurization ratio are shown in Figs. 11 and 12. As shown in Fig. 11, the sulfur removal rate is improved obviously with the decrease of powder particles diameter. The surface area of the transitory desulphurization reaction is increased with the decrease of powder particles diameter, which is conducive to increasing the desulphurization reaction rate. The change of sulphur content in liquid steel is $0.97 \mathrm{ppm}, 1.39 \mathrm{ppm}, 1.61 \mathrm{ppm}, 2.15 \mathrm{ppm}$ when powder particles diameter decreases in the range of (0.8-0.7) mm, (0.7-0.6) mm, (0.6-0.5) mm, (0.5-0.4) mm,

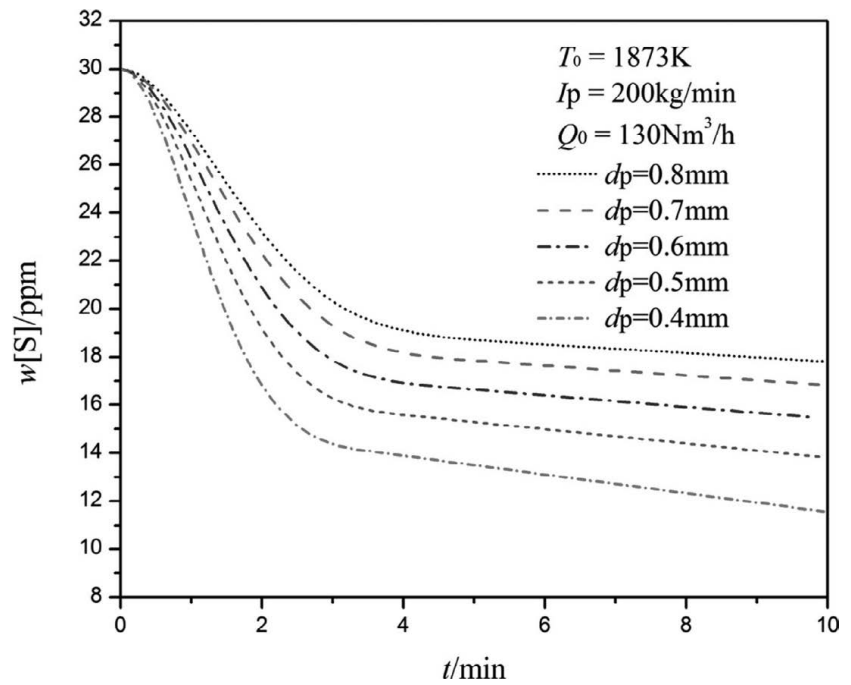

Fig. 11. Effect of powder particles diameter on desulphurization process.

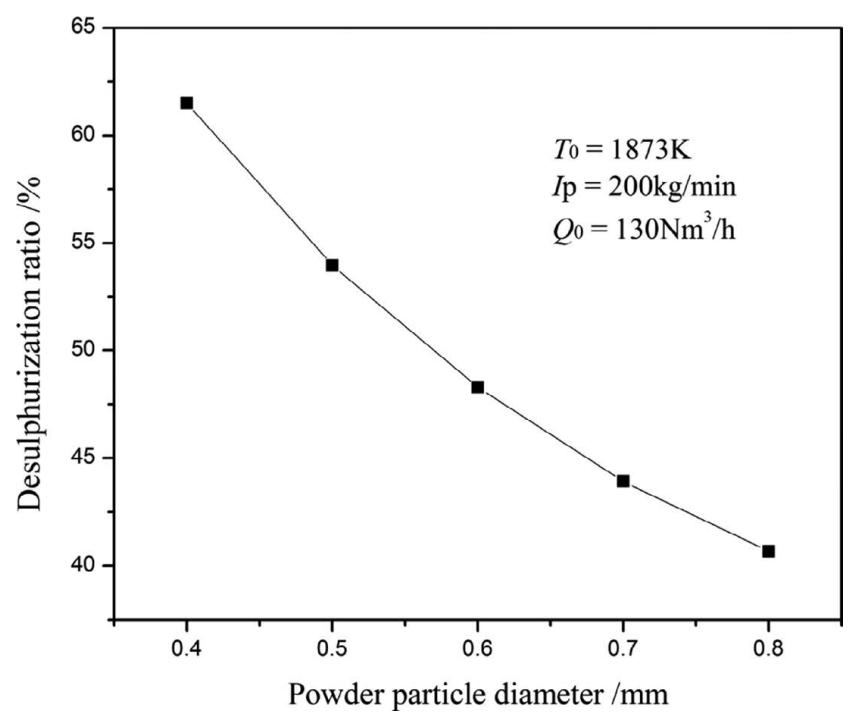

Fig. 12. Effect of powder particles diameter on desulphurization ratio.

respectively after treating $10 \mathrm{~min}$. As shown in Fig. 12, the desulphurization ratio is increased with the decrease of powder particles diameter and presents an increasing trend. It is well known that too small powder particles are easy to be taken away by driving gas and smaller powder particles are more likely to be sucked into the whirlpool which leads to the circulation utilization rate of powder particles reducing. Even though the water model simulation experiment cannot reflect the chemical reaction of desulphurization, but the physical parameters concerning about the movement of flux particles and molten steel which are very important for kinetic model of RH refining can be obtained by the water model simulation experiment. So the physical simulating desulphurization by powder injection with a water model of the practical $300 \mathrm{t}$ RH was conducted in our lab. The physical parameters such as mixing time of powder particles in molten pool $\left(\tau_{\mathrm{m}}\right)$, penetration ratio of powder particles $(\beta)$, etc., were obtained from the simulating experiments and listed in Table 4, which were used in the present kinetics model. Seen from Table 4, according to the physical experiment results by water model, the penetration ratio of powder 
particles is stabilized at about $97 \%$ when the diameter of the powder particles is in the range of $0.35 \mathrm{~mm}$ to $1 \mathrm{~mm}$. However, the penetration ratio of powder particles is $57.1 \%$ if the diameter is $0.2 \mathrm{~mm}$ by the formula used to calculate the penetration ratio for particles with diameter in the range of $0.15 \mathrm{~mm}$ to $0.3 \mathrm{~mm}$. The effect of powder particle diameter decreasing on the enhancement of desulphurization reaction was largely offset and the amount of powder particles taken away with the driving gas greatly increased in RH actual operation. The advised diameter of powder particle is in the range $0.35 \mathrm{~mm}$ to $1 \mathrm{~mm}$ according to the calculated results combined with physical simulating.

\subsection{Effect of the Flow of Driving Gas on Desulphuriza- tion Process}

The effect of the flow of driving gas on desulphurization process and desulphurization ratio are shown in Figs. 13 and 14 according to the calculated results. Figure 13 indicates the change of sulphur content in liquid steel is not apparent before treating $3 \mathrm{~min}$ and it reaches to $0.56 \mathrm{ppm}, 0.67 \mathrm{ppm}$

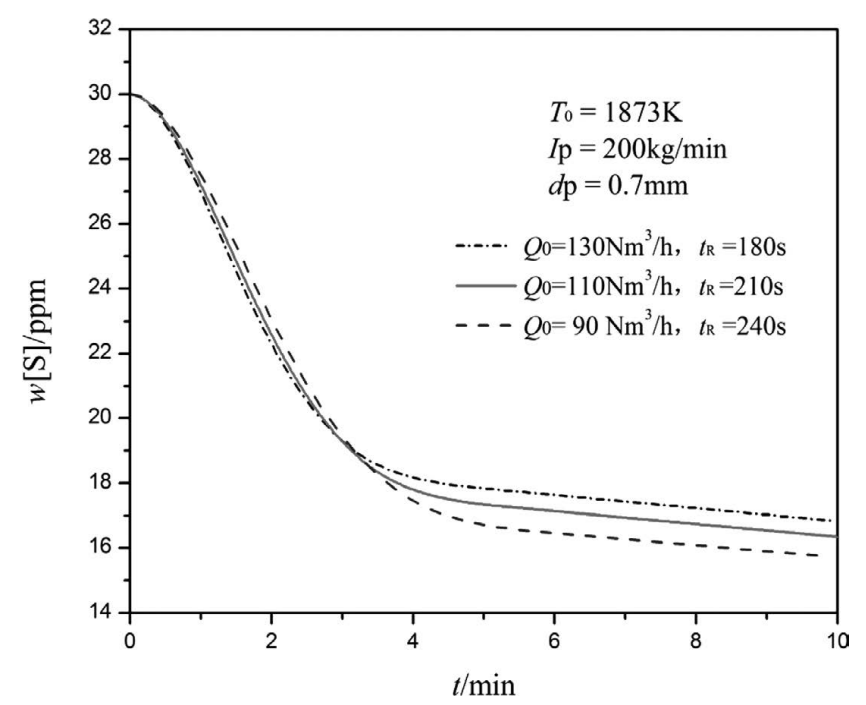

Fig. 13. Effect of the flow rate of the driving gas on desulphurization process.

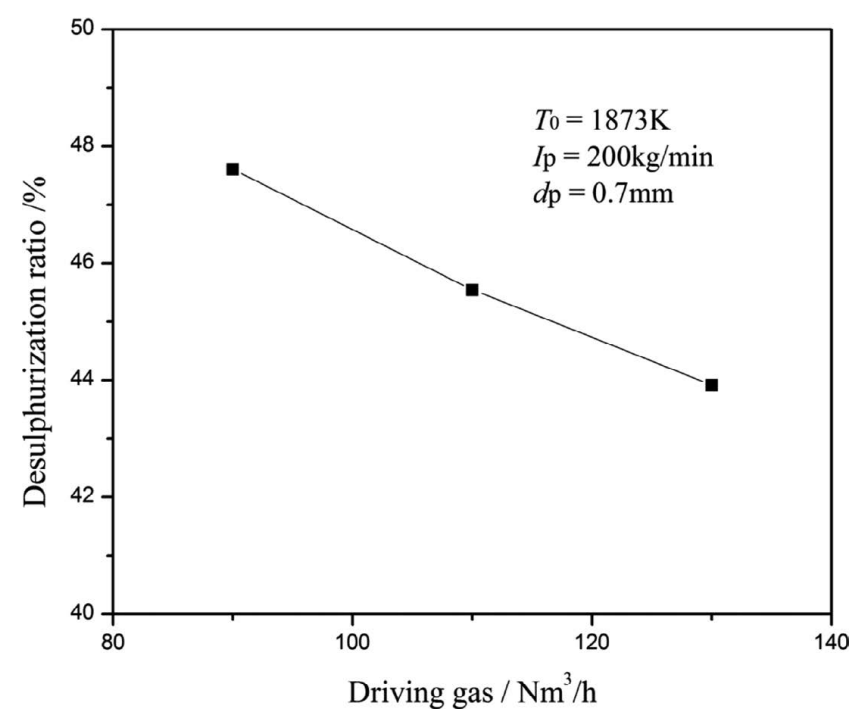

Fig. 14. Effect of the flow rate of the driving gas on desulphurization ratio. when the flow of driving gas decreases from $130 \mathrm{Nm}^{3} / \mathrm{h}$ to $110 \mathrm{Nm}^{3} / \mathrm{h}, 110 \mathrm{Nm}^{3} / \mathrm{h}$ to $90 \mathrm{Nm}^{3} / \mathrm{h}$ respectively after treating $10 \mathrm{~min}$. The circulation flow of liquid steel decreases and the mass transfer of sulphur in liquid steel side reduce slowly with the decrease of the flow of driving gas, which is not conducive to the desulphurization reaction. On the other hand, the average residence time of powder particles in the liquid steel is prolonged when the flow of driving gas decreases which will promote desulphurization reaction and then gets a higher sulfur removal rate. As shown in Fig. 14, the desulphurization ratio increases with the decrease of the flow of driving gas.

\subsection{Effect of Initial Temperature of the Bath on Desul- phurization Process}

The effect of initial temperature of the bath on desulphurization process and desulphurization ratio are shown in Figs. 15 and 16. The change of sulphur content in liquid steel is $0.316 \mathrm{ppm}$ when initial temperature of the bath changes between $1773 \mathrm{~K}$ and $1823 \mathrm{~K}$. The change of sul-

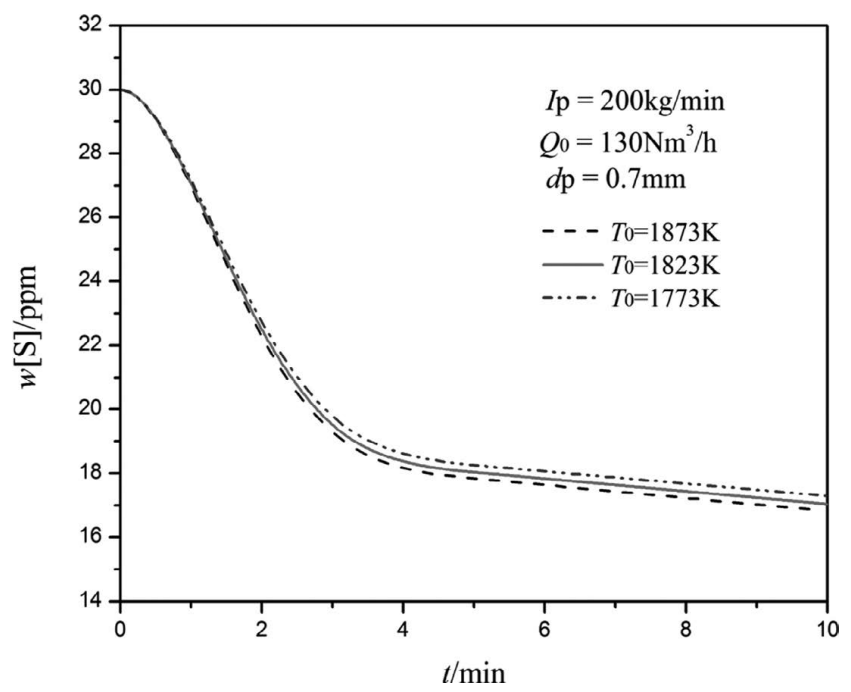

Fig. 15. Effect of initial temperature of liquid steel on desulphurization process.

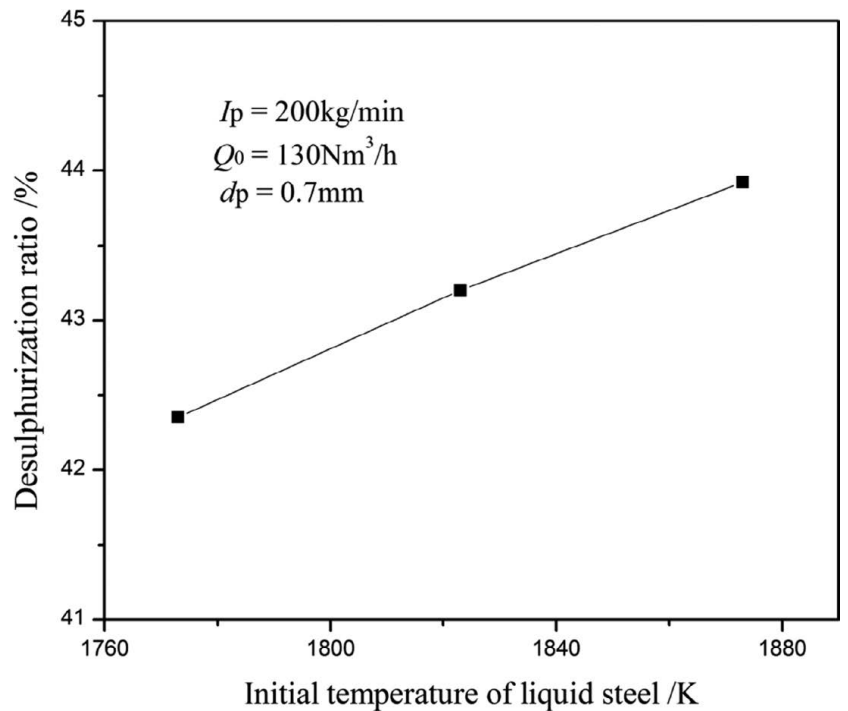

Fig. 16. Effect of initial temperature of liquid steel on desulphurization ratio. 
phur content in liquid steel is $0.355 \mathrm{ppm}$ when the initial temperature in bath changes between $1823 \mathrm{~K}$ and $1873 \mathrm{~K}$. It is limited to increasing initial temperature of the bath to improve the mass transfer of sulphur in liquid steel. Higher temperature benefits to desulphurization reaction according to thermodynamics point and desulphurization ratio increases which can be seen from Fig. 16.

\section{Conclusion}

A mathematical model based on the conditions of desulphurization thermodynamics, kinetics and practical production is proposed for the prediction of sulphur evolution in liquid steel during RH treatment. The main results can be summarized as follows:

(1) Transitory desulphurization reaction plays an absolute role in the total desulphurization reaction, and the contribution ratio of transitory reaction maintains more than $98.52 \%$.

(2) The effect of initial sulphur content, powder particles diameter and driving gas flow rate on temperature drop in the bath is low. While the temperature drop increases 7.73 $\mathrm{K}$ when the powder injection rate varies from $150 \mathrm{~kg} / \mathrm{min}$ to $300 \mathrm{~kg} / \mathrm{min}$ and decreases $3.36 \mathrm{~K}$ when the initial temperature decreases from $1873 \mathrm{~K}$ to $1773 \mathrm{~K}$.

(3) The desulphurization ratio increases slightly with the increase of initial sulphur content in the liquid steel. It is the key to controlling the initial sulphur content of the liquid steel before RH treatment to get lower final sulphur content in the steel and an economic total desulphurization load.

(4) The desulphurization ratio increases with the increase of powder injection rate and the decrease of powder diameter. The advised diameter of powder particle is in the range of $0.35 \mathrm{~mm}$ to $1 \mathrm{~mm}$ for more conducive to actual production. Reducing the flow rate of the driving gas appropriately can slightly increase the desulphurization ratio.

(5) Lower final sulphur content can be obtained by increasing the powder injection rate, decreasing the powder particles diameter and the driving gas in the actual operation process. The lowest sulphur content which is $10 \mathrm{ppm}$ can be obtained when the initial sulphur content of liquid steel is about $30 \mathrm{ppm}$, the initial temperature of liquid steel is 1873 $\mathrm{K}$, the driving gas is $130 \mathrm{Nm}^{3} / \mathrm{h}$, the powder injection rate is controlled in the range of (150-250) kg/min, and the powder particles diameter is controlled in the range of (0.15-0.4) $\mathrm{mm}$ after treating $10 \mathrm{~min}$.

\section{Acknowledgement}

This work was funded by the National Natural Science Foundation of China (No. 51104109, No. 51541409) and China Postdoctoral Science Foundation (No. 2013M540609). The authors of this paper thank the National Natural Science Foundation of China and China Postdoctoral Science Foundation.

\section{REFERENCES}

1) M. Y. Zhu: Modern Metallurgy (Steel Metallurgy volume), Metallurgical industry Press, Beijing, (2005) (in Chinese).

2) J. Lehmann and M. Nadif: Rev. Mineral. Geochem., 73 (2011), 493.

3) M. S. Millman: Ironmaking Steelmaking, 26 (1999), 169.

4) S. F. Wu, Q. F. Ma and B. L. He: Spec. Steel, 34 (2013), 28 (in Chinese).

5) H. Z. Wu, M. T. Song and H. Z. Wang: World Iron Steel, 9 (2009), 22 (in Chinese).

6) M. L. Lobanov, G. M. Rusakov and A. A. Redikul'tsev: Phys. Met. Metallogr., 114 (2013), 559.

7) K. Matsumura and B. Fukuda: IEEE Trans. Magn., 20 (1984), 1533.

8) O. Yoshihiko, T. Yasushi, Y. Nobuo, C. Atsushi and Y. Katsumi: NKK Tech. Rev., 87 (2002), 12.

9) M. Q. Yu, Z. H. Wang, M. H. Xu and J. X. Chen: Iron Steel, 41 (2006), 26 (in Chinese).

10) S. Takaishi, T. Komai, Y. Mizukami, I. Kobayashi and T. Kusunoki: Tetsu-to-Hagané, 66 (1980), S131.

11) V. D. Knoop, W. Tiekink and V. P. Jong: Rev. Metall.-CIT, 93 (1996), 533.

12) T. Furusaki, H. Inaba, H. Takamoto, M. Yoshii and S. Yagura: Tetsuto-Hagané, 72 (1986), S261.

13) K. Endo: Seitetsu Kenkyu, 335 (1989), 20.

14) T. Hatakeyama, Y. Mizukami, K. Iga and M. Oita: Iron Steelmaker, 15 (1989), 23.

15) Y. Okada: Tetsu-to-Hagané, 80 (1994), 9.

16) H. Okano, M. Satoh, K. Tada, K. Shinme, S. Fukagawa, N. Kurokawa and Y. Tajiri: 80th Steelmaking Conf., Chicago, (1997), 127.

17) N. V. Poucke, L. Peeters and F. Haers: Rev. Metall.-CIT, 97 (2000), 527.

18) J. Z. Zheng, Z. Z. Huang, H. C. Fei and L. X. Zhu: Baosteel Technol., (1999), 33 (in Chinese).

19) W. K. Peng and L. P. Lin: Wuhan Iron Steel, 16 (2000), 21 (in Chinese).

20) H. T. Hu, Z. G. Ma, X. F. Jiang and Z. Z. Huang: Steelmaking, 29 (2013), 52 (in Chinese).

21) J. H. Wei, S. J. Zhu and N. W. Yu: Acta Metall. Sin., 34 (1998), 497 (in Chinese).

22) T. Hiraoka, K. Ohnuki, H. Fujii, K. Fukuda and Y. Hoshijima: Tetsuto-Hagané, 89 (2003), 48.

23) Z. Zulhan, C. Schrade and Y. A. Patriona: SEAISI Conf. and Exhibition, SEAISI Q. J., Pattaya, (2013), 32.

24) Y. N. Chen, Y. P. Bao, M. Wang and L. H. Zhao: Metall. Res. Technol., 111 (2014), 37.

25) X. Chushao and T. Xin: ISIJ Int., 32 (1992), 1081.

26) V. Seshadri, C. A. Silva, I. A. Silva Da and P. Kruger: ISIJ Int., 37 (1997), 21.

27) G. Roy, P. Chaudhary, P. Minj and R. Goel: Metall. Mater. Trans B., 32 (2001), 558.

28) P. C. Yan, X. L. Guo, S. G. Huang, V. D. Joris, M. X. Guo and B. Bart: ISIJ Int., 53 (2013), 459.

29) C. L. Zhao: Ph. D. Thesis, North. Univ., (2006), (in Chinese).

30) Y. Kawai and Y. Shirishi: Handbook of Physico-Chemical Properties at High Temperature. ISIJ, Tokyo, (1988), 105.

31) R. E. Treybal: Mass-transfer Operations. McGraw-Hill, New York, (1955), 968.

32) T. Komai, Y. Mizukami, K. Iga and T. Kusunoki: Tetsu-to-Hagané, 69 (1983), 238.

33) Z. Q. Sun, M. F. Jiang, L. K. Liang and Y. C. Che: J. Iron Steel Res, 16 (2004), 23 (in Chinese).

34) R. W. Young, J. A. Duffy, G. J. Hassall and Z. Xu: Ironmaking Steelmaking, 19 (1992), 201.

35) C. Wagner, S. Mellgren and J. H. Westbrook: Thermodynamics of Alloys, Vol. 4, Addision-Wesley Press, CA, (1952).

36) H. Itoh, M. Hino and B. Y. Shiro: Tetsu-to-Hagané, 83 (1997), 773.

37) X. H. Huang: The Principle of Ferrous Metallurgy, Metallurgical industry Press, Beijing, (2005), 181 (in Chinese).

38) X. Xu, W. G. Cheng, F. Feng and D. Yao: MATLAB5.3 Application Guide, Posts \& Telecom Press, Beijing, (1999), 156 (in Chinese).

39) Z. G. Wang, C. Gong and Q. He: Proficient in MATLAB Scientific Computing, Publishing House of Electronics Industry, Beijing, (2007), 180 (in Chinese)

40) L. Liu: Iron Steel, 41 (2006), 1 (in Chinese). 